\title{
IgY Production by Taiwan Native Tsaiya Ducks and White Leghorn Laying Hens
}

\author{
Yi-Fan Lin ${ }^{1}$, Jenn-Fa Liou ${ }^{2}$, Lih-Ren Chen ${ }^{2} \&$ Tu-Fa Lien ${ }^{1}$ \\ ${ }^{1}$ Department of Animal Science, National Chiayi University, Chiayi, Taiwan, R.O.C. \\ ${ }^{2}$ Division of Physiology, Livestock Research Institute, Council of Agriculture, Tainan, Taiwan, R.O.C. \\ Correspondence: Tu-Fa Lien, Department of Animal Science, National Chiayi University, Chiayi, Taiwan, R.O.C. \\ Tel: 886-5271-7536. E-mail: tflien@mail.ncyu.edu.tw
}

Received: May 15, 2014 Accepted: July 8, 2014 Online Published: August 15, 2014

doi:10.5539/jas.v6n9p106

URL: http://dx.doi.org/10.5539/jas.v6n9p106

\begin{abstract}
The aim of this study was conducted to investigate a method to production purify IgY and compare the capacity between Taiwan native Tsaiya ducks (layer type) and Leghorn laying hens. Ten Taiwan native Tsaiya ducks and 10 white Leghorn laying hens ( 20 wk-old) were injected with $250 \mu \mathrm{L}$ of complete Freund's adjuvant containing bovine serum albumin (BSA, 200mg) during week 1 of the trial. The boost injection, during week 2 and 4 of the trial was comprised $250 \mu \mathrm{L}$ of incomplete Freund's adjuvant containing BSA was conducted to promote IgY production. Eggs were collected for IgY purification from the week 5 of the trial. Yolk protein was first extracted using isopropanol or triton and followed by salting out with ammonium sulfate. After dialysis, gel filtration chromatography and affinity chromatography were used to purify the IgY antibody. Yolk proteins extracted by isopropanol or triton from duck eggs were $43 \%$ and $13 \%$, and $61 \%$ and $16 \%$ from hen eggs, respectively. After salting out, the duck $\operatorname{IgY}$ had a purity of $53-57 \%$ with a titer of $26.2-29.9$ unit $/ \mathrm{mg}$ protein, while the hen $\operatorname{IgY}$ had a purity of $45-50 \%$ with $24-29.5$ unit/mg protein. After purification by gel filtration chromatography, the purity of the duck IgY was increased to $89-90 \%$ with $44.24-50.62$ folds purification and $415-451 \mathrm{unit} / \mathrm{mg}$ protein. The purity of the chicken hen IgY was increased to $85-87 \%$ with $29.85-30.38$ folds purification and 240-277.6 unit/mg protein. After further purification by affinity chromatography, duck IgY purity was increased to $91-92 \%$ with $45-56.26$ folds purification and $459-461 \mathrm{unit} / \mathrm{mg}$ protein; chicken hen IgY purity was increased up to $93-95 \%$ with $33.58-59.49$ folds purification and $312-470$ unit $/ \mathrm{mg}$ protein. This procedure is promising for purification and production of the IgY antibody from Taiwan native Tsaiya ducks and/or white Leghorn laying hens, and both of them are good producer of IgY.
\end{abstract}

Keywords: IgY antibody, Tsaiya ducks, laying hens, protein purification

\section{Introduction}

Most commercial antibodies are produced from rabbits, rats or sheep. Generally, the procedure to produce antibodies starts with antigen immunization, followed by blood collection to isolate the antibodies, and then further purification. The blood collection process stresses the animals, and large amount of blood harvested also adversely affects animal health. Thus, the life and productive of animals are reduced as blood collection increases. In comparison, the advantages of using poultry for antibody production are as follows: (1) the number of mammals used can be reduced as poultry can produce larger amounts of antibodies (100-150 mg/per egg) than mammals; and (2) blood collection from mammals can be replaced by antibody extraction from egg yolk, thus, use the non-invasive method animals are not stressed (Karlsson et al., 2004). One egg contains roughly $375 \mathrm{mg}$ of antibodies (Rose et al., 1974), and one head layer can lay 280 eggs per year. Therefore, it is a potent and economical approach to use poultry for antibody production.

Mammalian blood contains 5 antibody types-IgA, IgM, IgE, IgD and IgG. The IgG antibody is the most abundant. On the other hand, poultry eggs contain IgY, IgA and IgM, which are the same as those in mammals. IgY (immunoglobin from yolk) is similar to mammalian IgG. The molecular weight of IgY is higher than that of IgG (180 v.s $150 \mathrm{KDa}$ ) (Tini et al., 2002; Zhang, 2003). The IgY antibody is the antibody transferred from blood IgG to the egg yolk, a process similar to the transfer of mammalian blood antibodies to an embryo; this is a passive immune process. As IgY is more lipidphilic than IgG, it can reside in lipid-rich yolk. In addition, the $\mathrm{pH}$ of iso-electric point of IgY is also lower than that of IgG (Davalos-Pautoja et al., 2000). 
Either avian IgY antibody or mammalian IgY can used for (1) experimental analysis (e.g. ELISA) or disease diagnosis; (2) detoxification of toxic materials; and, (3) prevention and treatment of diseases (Reilly et al., 1997; Yokoyama et al., 1992). Reilly et al. (1997) indicated that IgY can prevent and cure intestinal diseases such as human or cattle rotavirus, enterotoxigenic, E. Coli, Salmonella ssp., and Helicobacter pylori infection (Yolken et al., 1988; Ikemori et al., 1992; Karlsson et al., 2004). Therefore, IgY is a potential substitute for antibiotics. Our previous study also indicated that the anti E. Coli and and Helicobacter pylori IgY can specific bind to the bacterias (Liou et al., 2010; Siriya et al., 2013).

The Taiwan native Tsaiya duck, a breed that has a high egg production of eggs (280-300 eggs per year) and is highly disease resistant, may be a good producer of IgY. Thus, this study used the Taiwan native Tsaiya ducks and Leghorn laying hens to develop a method for producing highly purity ( $>90 \%) \operatorname{IgY}$, and compare the capacity of IgY production between this two fowls.

\section{Material and Methods}

\subsection{Immunization}

This study used 10 Tsaiya ducks and 10 white Leghorn laying hens (each roughly 20 wks-old). The birds were fed with a commercial diet and follow the guide of feeding program. During experimental week 1, the ducks and hens were injected with $250 \mu \mathrm{L}$ complete Freund's adjuvant with bovine serum albumin (BSA, 200mg) i.p. and then again, after 2 and 4 weeks, with $250 \mu \mathrm{L}$ of incomplete Freund's adjuvant of BSA to boost the antibodies production. Blood samples were harvested during week 5 to determine the serum IgG level with an ELISA kit (Life Science Inc, Wuhan, China). Elevated serum IgG level indicated that egg collection should start (Cook et al., 2001).

\subsection{Yolk Protein Extraction}

Method 1: The procedure described by Bade and Stegemann (1984) was followed. Briefly, yolk was separated from egg white, collected and mixed with an equal of PBS buffer, isopropanol $(100 \mathrm{~mL})$ was added to the mixture, put in $4{ }^{\circ} \mathrm{C}$ for $4 \mathrm{~h}$ and then, centrifuged at $2665 \mathrm{~g}$ (Beckman, GS-15R, USA) for $15 \mathrm{~min}$ to separate yolk fat. This procedure was repeated 3 times. The PBS with $0.01 \% \mathrm{NaN}_{3}$ was added to the precipitate, which was allowed to stand at room temperature for $1 \mathrm{~h}$, then centrifuged at $8497 \mathrm{~g}, 25^{\circ} \mathrm{C}$ for $30 \mathrm{mins}$, and filtered using No.1 filter paper.

Method 2: The procedure reported by Stalberg and Larsson (2001) was followed. Briefly, yolk was separated from egg white, collected and mixed with an equal of PBS buffer. Then, triton X-100 (about 1/10 of the sample solution volume) was added and stirred for $1 \mathrm{~h}$. Centrifugation at $1499 \mathrm{~g}$ for 25 mins was used to separate fat and protein layers. The protein layer was obtained to which $12 \%$ polyethylene glycol (PEG) was added, and centrifuged again at $8497 \mathrm{~g}$ for 25 mins. The pellet was taken and added PBS again before filtering.

\subsection{Salting out to Separate IgY}

Ammonium sulfate was slowly added to the collected egg protein solution. The protein solution was then centrifuged at $8497 \mathrm{~g}$ for 15 mins, the pellet was obtained and phosphate buffer $(\mathrm{pH} 7.8)$ was added for protein suspension. The protein solution was centrifuged at $2041 \mathrm{~g}$ for $15 \mathrm{mins}$. The protein fraction at the bottom of tube was added PBS for suspension. Dialysis of the protein solution with a membrane (Spectra/Por Cellulose Ester membrane MWCO:100000) was performed to remove the remaining salt (Hansen et al., 1998; Cook et al., 2001).

\subsection{Purification of IgY by Gel Filtration and Affinity Chromatography}

Gel filtration chromatography: The Column was prepared with sephacyl G-100, column elution for 20 mins with elution buffer (phosphate buffer; $\mathrm{pH}$ 7.8). Sample solution ( $1 \mathrm{~mL}$ ) was infused into the column and the different fractions were collected with a fraction collector and monitored with an OD280 until no peaks appeared. All samples was tested the titer, and those high titer samples were pooled (Cook et al., 2001; Hansen et al., 1998).

Affinity chromatography: Specific ligand (protein A affinity resin) pack in an affinity column (Econo-Pac Blue Cartridges) was used to bind $\mathrm{IgY}, 1 \mathrm{~mL}$ of the sample was infused into the column, then eluted with buffer (sodium citrate, $\mathrm{pH} 5.5$ ) to extract IgY, and neutralized with Tris- $\mathrm{HCl}(\mathrm{pH} 8.5$ ) immediately.

\subsection{Protein Quantification, Purity Determination of $\operatorname{Ig} Y$ and Titer Determination of $\operatorname{Ig} Y$}

The protein content in the sample was determined using either the Biuret method or Lowry method (Lowry et al., 1951). The IgY purity was determined by SDS-PAGE and a commercial IgY (Sigma) was used as the standard. The concentration of bands was examined using a densitometer (Helena, Model Bjf 00105, USA). The IgY titers were measured with the ELISA method, and commercial IgY was used as the standard (Leslie \& Frank, 1989). 


\section{Results and Discussion}

Table 1 shows the serum IgG concentration in Leghorn chickens and Tsaiya ducks at the start of the trial and after the third immunization. After 3 immunizations (week 7 of the experiment), the serum IgG level in Leghorn layer hens and Tsaiya ducks were increased significantly, this outcome consistent experimental results obtained by Sunwoo et al. (2002), who also indicated that the antibody titer peaks after 3 immunizations.

Table 1. The serum total IgG concentration in white Leghorn chicken and Taiwan native Tsaiya duck before immunization and after the third immunization

\begin{tabular}{ccc}
\hline Items & Before immunization $(0$ week $)$ & Third immunization $\left(7^{\text {th }}\right.$ week $)$ \\
\hline & $-112.3 \pm 8.4$ & $1967.2 \pm 123$ \\
Leghorn Chicken & $66.1 \pm 2.9$ & $1590.9 \pm 113$ \\
Tsaiya Duck & & \\
\hline
\end{tabular}

*Immunization time: 0, 2, 4 week.

Means $\pm \mathrm{SD}(\mathrm{n}=10)$.

After the second immunization booster, antibody production level exceeds that generated by the first immunization, and the produced antibody is primarily $\operatorname{IgG}$ with great antigen affinity ability, that is, the memory B cell has the immunoglobin membrane.

Tables 2 and 3 shows the titer and purity of $\operatorname{IgY}$ obtained from the egg yolk of chickens and ducks after extraction and purification steps, respectively. Experimental results show that chicken egg yolk extracted by isopropanol or triton were $61 \%$ and $16 \%$ isolated protein, while the duck egg yolk were $43 \%$ and $13 \%$ isolated protein, respectively. When the yolk protein was salted out by ammonia sulfate, the resultant purity in the duck group was $53-57 \%$ (Figure 1); the titer was $26.2-29.9$ unit $/ \mathrm{mg}$ protein. On the other hand, the chicken group had a purity of $45-50 \%$ (Figure 1) and the titer was $24-29.5 \mathrm{unit} / \mathrm{mg}$ protein. After purification by gel filtration chromatography, the resultant purity, relative purification fold and titer from the duck group were $89-90 \%$ (Figure 2), 44.24-50.62 and 415-451U, respectively. The chicken group had 85-87\% purity (Figure 2), relative purification fold of $29.85-30.38$ and $240-277.6 \mathrm{U}$ titer. Final purification by affinity chromatography had generated $91-92 \%$ purity (Figure 2), 45-56.26 relative purification fold and 459-61U titer in the duck group, while those of the chicken group were $93-95 \%$ purity (Figure 2), 33.58-59.49 relative purification fold, and $312-470 \mathrm{U}$ titer. Gel filtration and affinity chromatography indicated that purity can reach up to $90 \%$; thus, it is a good approach for extraction and purifying the IgY antibody.

Table 2. Titer and purity of IgY obtained from egg yolk of White Leghorn chicken after extraction and purification steps

\begin{tabular}{|c|c|c|c|c|c|c|c|c|c|c|}
\hline \multirow{2}{*}{ Methods } & \multicolumn{2}{|c|}{ Protein $(\mathrm{mg})$} & \multicolumn{2}{|c|}{$\operatorname{Titer}^{\mathrm{b}}(\mathrm{U} / \mathrm{mg}$ protein $)$} & \multicolumn{2}{|c|}{ Relative purity (fold) } & \multicolumn{2}{|c|}{ Purification (\%) } & \multicolumn{2}{|c|}{ Recovery $(\%)$} \\
\hline & 1 & 2 & 1 & 2 & 1 & 2 & 1 & 2 & 1 & 2 \\
\hline Crude extract ${ }^{a}$ & 1782 & 469 & 7.9 & 9.3 & 1 & 1 & - & - & 100 & 100 \\
\hline Salting out $\left(\mathrm{NH}_{4}\right)_{2} \mathrm{SO}_{4}$ & 52.62 & 39.51 & 24.0 & 29.5 & 3.04 & 3.29 & 45 & 50 & 8.97 & 26.72 \\
\hline Gel filtration chromatography & 2.55 & 2.33 & 240 & 277.6 & 30.38 & 29.85 & 85 & 87 & 4.35 & 14.83 \\
\hline Affinity chromatography & 1.25 & 1.75 & 470 & 312.3 & 59.49 & 33.58 & 93 & 95 & 4.17 & 12.53 \\
\hline
\end{tabular}

Chicken egg contains protein amount of $2.93 \mathrm{~g} /$ per yolk $(15 \mathrm{~mL})$.

* Used ten eggs in this analysis.

Method 1: isopropanol. Method 2: triton.

${ }^{a}$ The protein content in the crude extract step of method 1 and 2 were 61 and $16 \%$ of the egg yolk, respectively.

${ }^{\mathrm{b}}$ The IgY titers were measured with the ELISA method, and commercial IgY was used as the standard. 
Table 3. Titer and purity of IgY obtained from egg yolk of Taiwan native Tsaiya duck after extraction and purification steps

\begin{tabular}{|c|c|c|c|c|c|c|c|c|c|c|}
\hline \multirow{2}{*}{ Methods } & \multicolumn{2}{|c|}{ Protein (mg) } & \multicolumn{2}{|c|}{$\operatorname{Titer}^{\mathrm{b}}$ (U/mg protein) } & \multicolumn{2}{|c|}{ Relative purity (fold) } & \multicolumn{2}{|c|}{ Purification (\%) } & \multicolumn{2}{|c|}{ Recovery (\%) } \\
\hline & 1 & 2 & 1 & 2 & 1 & 2 & 1 & 2 & 1 & 2 \\
\hline Crude extract ${ }^{\mathrm{a}}$ & 1654 & 501 & 8.2 & 10.2 & 1 & 1 & - & - & 100 & 100 \\
\hline Salting out $\left(\mathrm{NH}_{4}\right)_{2} \mathrm{SO}_{4}$ & 59.61 & 38.92 & 29.9 & 26.2 & 2.43 & 2.57 & 53 & 57 & 13.14 & 19.94 \\
\hline Gel filtration chromatography & 3.55 & 2.05 & 415.1 & 451.2 & 50.62 & 44.24 & 90 & 89 & 10.86 & 18.10 \\
\hline Affinity chromatography & 2.63 & 1.55 & 461.3 & 459.0 & 56.26 & 45 & 91 & 92 & 8.95 & 13.92 \\
\hline
\end{tabular}

Duck egg contains protein amount of $3.84 \mathrm{~g} /$ per yolk $(18 \mathrm{~mL})$.

* Used ten eggs in this analysis.

Method 1: isopropanol. Method 2: triton.

${ }^{\text {a }}$ The protein content in the crude extract step of method 1 and 2 were 43 and $13 \%$ of the egg yolk, respectively.

${ }^{\mathrm{b}}$ The IgY titers were measured with the ELISA method, and commercial IgY was used as the standard.

(A)

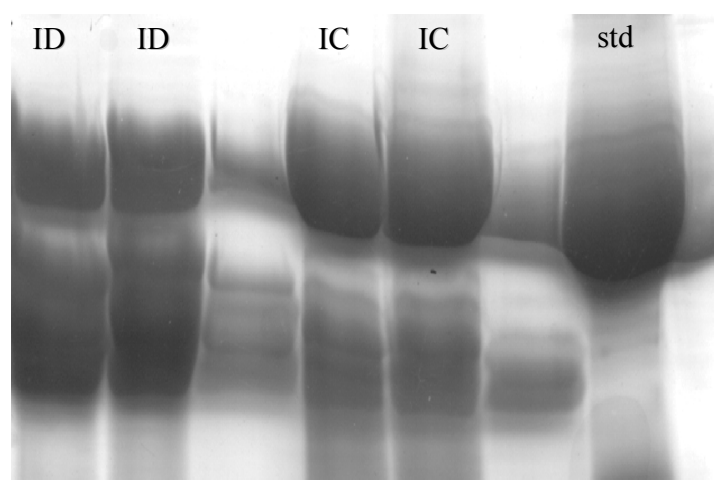

(B)

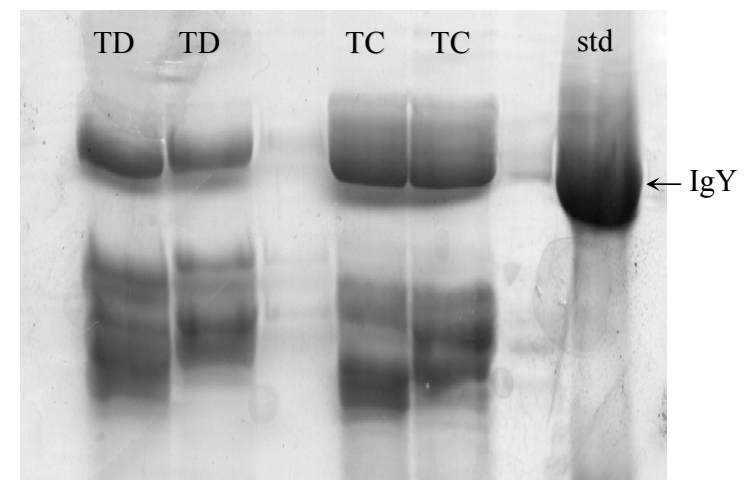

Figure 1. IgY SDS-PAGE image after salting out with ammonium sulphate (A) Isopropanol method (B) Triton method. I: isopropanol, T: triton, C: chicken, D: duck, std: standard (IgY)

(A)

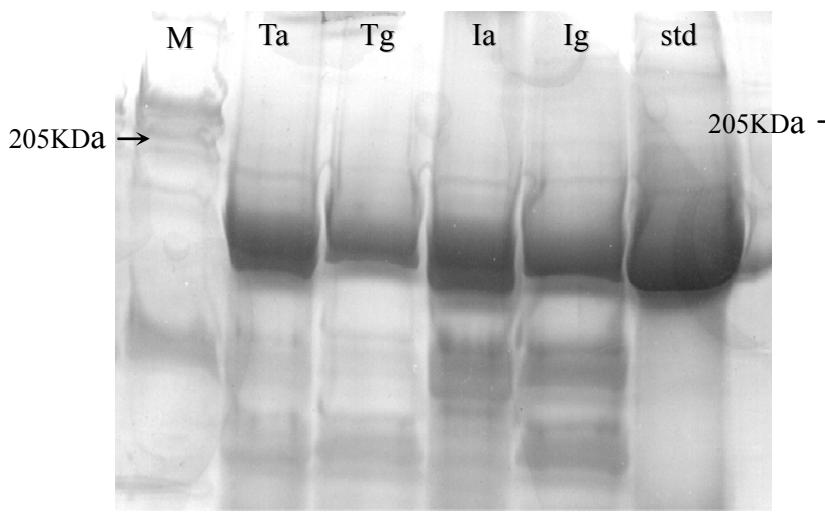

(B)

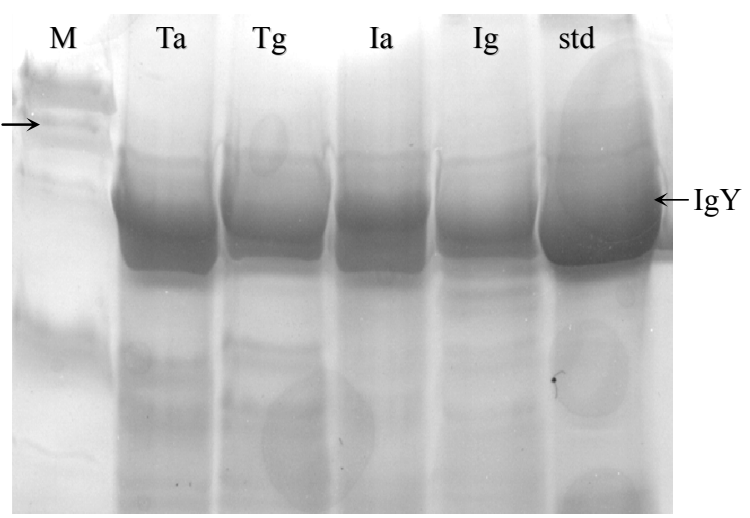

Figure 2. IgY SDS-PAGE image after gel filtration and affinity chromatography (A) White Leghorn chicken (B)Tsaiya duck. I: isopropanol, T: triton, a: affinity, g: gel filtration, std: standard (IgY), M: protein molecular weight marker

Fat and protein are the major components of egg yolk. Fat, which includes triglycerides, phospholipids and cholesterol, account for about one-third of the yolk. Protein account for about 15-17\% of the yolk (Powrie, 1976), of which $30 \%$ are granules and $70 \%$ are plasma. The IgY is contained in plasma protein. Notably, IgY can be 
extracted using various methods. For instance, $\operatorname{IgY}$ can be extracted by extracentrifugation (McBee \& Cotterilly, 1979), polyethylene glycol (Polson et al., 1985), polyacryl acid resins (Hamada et al., 1991), sodium dextran sulfate (Jensenius et al., 1981), carrageenan and xanthan gum (Hatta et al., 1990). However, since yolk contains a large proportion of fat, yolk protein extraction involves either removal of the fat or separation of the protein fraction from fat. This study used the isopropanol-based method to remove the fat from the yolk. Isopropanol is a solvent that can dissolves fat. This method can effectively extracts large amounts of protein. However, this procedure can result in increased amounts of fat residue. The protein reaction with ammonia sulfate during salting out can be affected; thus, salting out efficiency is poor. Extraction using triton and polyethylene glycol (PEG) involves separation of the protein fraction from fat followed by protein isolation. The isolated yolk protein via this method may be cleaner than that generated by the isopropanol-base method; thus, the amount of IgY titer using the triton method was considerable; however, the amount of yolk protein produced was less than that generated by the isopropanol-base method. Compared to the experimental results obtained by Kwan et al. (1991), who used the water-soluble fraction method and obtained $60 \%$ of yolk protein, it is rapid and efficient method (Nilsson et al., 2008). This extraction method was low efficiency.

The extracted yolk protein was then fractionated by salting out with ammonia sulfate slowly to precipitate the soluble protein. The optimal amount of ammonium sulfate for precipitation of protein was $45-55 \%$; the salting out procedure was repeated 2-3 times.

After salting out using ammonia sulfate and dialysis, this study used gel filtration chromatography to purify IgY. This approach separates protein by particle size (or molecular weight). Yolk contains $\alpha, \beta$ and $\gamma$ proteins (livetin) and IgY is present in $\gamma$-livetin. The purpose of this separation step is to increase purification efficiency, as the next step used affinity chromatography, and the column for chromatography is expensive. Thus, if the sample contains much impure compounds, affinity column utility can be adversely affected and may reduce the purification efficiency. After gel filtration chromatography, the purity obtained was $>85 \%$. Neyestani et al. (2003) also successfully used the gel filtration chromatography to separate whey proteins with different molecular weights, and used advance ion exchange chromatography which, depending on different electron charges, isolates whey proteins such as $\alpha$-lactalbumin, $\beta$-lactoglobulin and bovine serum albumin.

The next IgY purification method employed was affinity chromatography. The ligand is protein A affinity resin. Higgins et al. (1995), who used proteins A and G affinity resin to purify antibodies, indicated that protein A ligand has good binding ability with duck IgY, and the amount of IgY produced in the protein A ligand was far higher than that generated by the protein G ligand $(49.30 \mathrm{mg}$ vs. $1.03 \mathrm{mg}$ ). Thus, Higgins et al. (1995) demonstrated that protein A affinity resin is a good ligand for purifying duck IgY. This study selected protein A affinity resin as the affinity chromatography column ligand. However, Schade et al. (2000) indicated that protein A is not a good binding ligand for chicken $\operatorname{IgY}$, this experiment was used protein A after filtration chromatography for purification of IgY, from the result also showed that not improved much of IgY purity. Other ligands, such as sepharose 4B, which is used to purify lactoferrin (Tu et al., 2001), are also highly efficient at purification.

Protein A resin, which originates from staphylococcus aureus and belongs to a cell wall protein, consists of A and B subunits. The B subunit, which has an $\alpha$-helix structure, can bind with the structure site of $\mathrm{CH}_{2}$ and $\mathrm{CH}_{3}$ of $\mathrm{IgY}$ or IgG. Through the interaction of the amino acid residue from IgY or IgG and protein A, the eggs histidine residues located at $\mathrm{CH}_{2}, \mathrm{CH}_{3}$ and $\mathrm{CH}_{4}$ can bind strongly with protein A ligand (Higgins et al., 1995).

After affinity chromatography, the IgY purity obtained was $93-95 \%$ and $91-92 \%$ in the chicken and duck groups, respectively (Figure 2 ); these percentages ( $>90 \%$ ) met this study goal.

Most studies have used chickens to produce IgY. This study, which compared IgY production from ducks with that of chickens, shows that total IgY titers using methods 1 and 2 in ducks was 1213.2 and $711.45 \mathrm{U}$, while 587.5 and 546.5 in chickens. The purity obtained from duck yolk was slightly lower than that from chicken yolk. In ducks two forms of low molecular weight of Ig's $7.8 \mathrm{~S}$ (Fab) and 5.7S (delta Fc) have been described, may be the efficient binding of the duck IgYs to protein A is high affinity binding, but cannot be binding to the Fc, since the IgY (delta Fc) does not have an Fc region (Higgins et al., 1995). The duck group produced more IgY titers than the chicken group; the egg producing ability of the Taiwan native Tsaiya duck is also not inferior to that of white Leghorn laying hens. Thus, the Taiwan native Tsaiya duck is also a good avian species for producing the IgY antibody.

\section{Conclusion}

The proposed procedure, including extraction of proteins containing IgY from Taiwan native Tsaiya ducks and white Leghorn laying hens used isopropanol or triton-100. After salting out using ammonia sulfate and 
purification with gel filtration and affinity chromatography, an IgY purity exceeding $90 \%$ was achieved. This is a promising approach for production of highly pure IgY, and both of Taiwan native Tsaiya ducks and white Leghorn laying hens are good producer of IgY.

\section{References}

Bade, H., \& Stegemann, H. (1984). Rapid method of extraction of antibodies from hen egg yolk. Journal of Immunological Methods, 72, 421-426. http://dx.doi.org/10.1016\%2F0022-1759\%2884\%2990010-3

Cook, C. L., Pao, W., Firca, J. R., Anderson, B. E., \& Fryer, J. P. (2001). Simple purification methods for an agalactose-specific antibody from chicken eggs. Journal of Bioscience and Bioengineering, 91, 305-310. http://dx.doi.org/10.1016\%2FS1389-1723\%2801\%2980139-0

Davalos-Pantoja, L., Ortega-Vinuesa, J. L., Bastos-Gonzalez, D., \& Hidalgo-Alvarez, R. A. (2000). Comparative study between the absorption of IgY and IgG on latex particles. Journal of Biomaterials Science, Polymer Edition, 11, 657-673. http://dx.doi.org/10.1163\%2F156856200743931

Hamada, S., Honkoshi, T., Minami, T., Kawabata, S., Hiraoka, J., Fujiwara, T., \& Ooshima, T. (1991). Oral passive immunization against dental caries in rats by use of hen egg yolk antibodies specific for cell-associated glucosyltransferase of Streptococcus mutans. Infection and Immunity, 59, 4161-4167.

Hansen, P., Scoble, J. A., Hanson, B., \& Hoogenraad, N. J. (1998). Isolation and purification of immunoglobulins from chicken eggs using thiophilic interaction chromatography. Journal of Immunological Methods, 215, 1-7. http://dx.doi.org/10.1016\%2FS0022-1759\%2898\%2900050-7

Hatta, H., Kim, M., \& Yamamoto, T. (1990). A novel isolation method for hen egg yolk antibody IgY. Agriculture Biology and Chemistry, 54, 2531-2535. http://dx.doi.org/10.1271\%2Fbbb1961.54.2531

Higgins, D. A., Chromie, R. L., Liu, S. S., Magor, K. E., \& Warr, G. W. (1995). Purification of duck immunoglobulins: an evaluation of protein A and protein $\mathrm{G}$ affinity chromatography. Veterinary $\begin{array}{llll}\text { Immunology and } \quad \text { Immunopathology, } & \text { 169-180. }\end{array}$ http://dx.doi.org/10.1016\%2F0165-2427\%2893\%2905300-4

Ikemori, Y., Kuroki, M., Peralta, R. C., Yokoyama, H., \& Kodama, Y. (1992). Protection of neonatal calves against fatal enteric colibacillus by administration of egg yolk powder from hens immunized with k99-pilated enterotoxigenic Escherichia coli. American Journal of Veterinary Research, 53, 2005-2008.

Jensenius, J. C., Andersen, I., Hau, J., Crone, M., \& Koch, C. (1981). Eggs: conveniently packaged antibodies. Methods for purification of yolk IgG. Journal of Immunological Methods, 46, 63-68. http://dx.doi.org/10.1016\%2F0022-1759\%2881\%2990333-1

Karlsson, M., Kollberg, H., \& Larsson, A. (2004). Chicken IgY: utilizing the evolutionary advantage. World's Poultry Science, 60, 341-347.

Kwan, L., Li, C. E., Helbig, N., \& Nakai, S. (1991). Fractionation of water-soluble and -insoluble components from egg yolk with minimum use of organic solvents. Journal of Food Science, 56, 537-1541. http://dx.doi.org/10.1111\%2Fj.1365-2621.1991.tb08635.x

Leslie, H., \& Frank, C. H. (1989). Practical Immunology (3rd ed., p. 23).

Liou, J. F., Lin, Y. F., Lien, T. F., Shiau, J. W., Tailiu, J. J., Tai, C., \& Chen, L. R. (2010). Production of egg yolk immunoglobulin against Escherichia coli from white Leghorn and Lohmann Layer. Taiwan Livestock Research, 43,181-193.

Lowry, O. H., Rosebrough, N. J., Farr, L., \& Randall, J. (1951). Protein measurement with Folin-phenol reagent. Journal of Biological Chemistry, 193, 265-275.

McBee, L. E., \& Cotterill, O. J. (1979). Ion-exchange chromatography and electrophoresis of egg yolk proteins. Journal of Food Science, 44, 656-660.

Neyestani, T. R., Djalali, M., \& Pezeshki, M. (2003). Isolation of $\alpha$-lactalbumin, $\beta$-lactoglobulin, and bovine serum albumin from cow's milk using gel filtration and anion-exchange chromatography including evaluation of their antigenicity. Protein Expression and Purification, 29, 202-208. http://dx.doi.org/10.1016\%2FS1046-5928\%2803\%2900015-9

Nilsson, E., Hanrieder, J., Bergquist, J., \& Larsson, A. (2008). Proteomic characterization of IgY preparations purified with a water dilution method. Journal of Agriculture and Food Chemistry, 56, 11638-42. http://dx.doi.org/10.1021\%2Fjf802626t 
Polson, A., Coetzer, T., Kruger, J., Von Maltzahn, E., \& Vac der Mewe, K. J. (1985). Improvements in the isolation of IgY from the yolks of eggs laid by immunized hens. Immunological Investigations, 14, $323-327$. http://dx.doi.org/10.3109\%2F08820138509022667

Powrie, W. D. (1976). Characteristics of edible fluids of animal origin: eggs. Principles of food science. Part 1. Food Chemistry, 7, 124-129.

Reilly, R. M., Domingo, R., \& Sandhu, J. (1997). Oral delivery of antibodies. Clinical Pharmacokinetics, 32 , 313-323. http://dx.doi.org/10.2165\%2F00003088-199732040-00004

Rose, M. E., Orlans, E., \& Buttress, N. (1974). Immunoglobulin classes in the hen's egg their segregation in yolk and white. European Journal of Immunology, 4, 521-523. http://dx.doi.org/10.1002\%2Feji.1830040715

Schade, R., Behn, I., Erhard, M., Hlinak, A., \& Staak, C. (2000). Chicken Egg Yolk Antibodies, Production and Application - IgY Technology. Springer, Berlin.

Siriya, P., Chu, C., Chen, M. T., Lo, C. C., Huang, S. L., \& Lien, T. F. (2013). Extraction and purification of anti-Helicobacter pylori IgY. Journal of Agriculture Science, 5, 132-138. http://dx.doi.org/10.5539\%2Fjas.v5n3p132

Stalberg, J., \& Larsson, A. (2001). Extraction of IgY from egg yolk using a novel aqueous two-phase system and comparison with other extraction methods. Upsala Journal of Medical Sciences, 106, 99-110. http://dx.doi.org/10.3109\%2F2000-1967-162

Sunwoo, H. H., Lee, E. N., Menninen, K., Suresh, M. R., \& Sim, J. S. (2002). Growth inhibitory effect of chicken egg yolk antibody (IgY) on Escherichia coli O157:H7. Journal of Food Science, 67, 1486-1494. http://dx.doi.org/10.1111\%2Fj.1365-2621.2002.tb10310.x

Tini, M., Jewell, U. R., Camenisch, G., Chilov, D., \& Gassmann, M. (2002). Generation and application of chicken egg-yolk antibodies. Comparative Biochemistry and Physiology-Part A, 131, 69-574. http://dx.doi.org/10.1016\%2FS1095-6433\%2801\%2900508-6

Tu, Y. Y., Chen, C. C., \& Chang, H. M. (2001). Isolation of immunoglobulin in yolk (IgY) and rabbit serum immunoglobulin $\mathrm{G}$ (IgG) specific against bovine lactoferrin by immunoaffinity chromatography. Food Research International, 34, 783-789. http://dx.doi.org/10.1016\%2FS0963-9969\%2800\%2900172-1

Yolken, R. H., Leister, F., Wee, S. B., Miskuff, R., \& Vonderfecht, S. (1988). Antibodies to rotavirus in chicken's egg: a potential source of antiviral immunoglobulins suitable for human consumption. Pediatrics, 81, 291-295.

Zhang, W. W. (2003). The use of gene-specific IgY antibodies for drug target discovery. Drug Discovery Today, 8 , 364-371. http://dx.doi.org/10.1016\%2FS1359-6446\%2803\%2902655-2

\section{Copyrights}

Copyright for this article is retained by the author(s), with first publication rights granted to the journal.

This is an open-access article distributed under the terms and conditions of the Creative Commons Attribution license (http://creativecommons.org/licenses/by/3.0/). 